INTERNATIONAL JOURNAL OF MULTIDISCIPLINARY RESEARCH AND ANALYSis

ISSN(print): 2643-9840, ISSN(online): 2643-9875

Volume 04 Issue 12 December 2021

DOI: 10.47191/ijmra/v4-i12-27, Impact Factor: 6.072

Page No.- 1962-1970

\title{
The Contribution of Staff Discipline and Promotion on the Development of Giwa Local Government Area
}

\author{
Byyiyet Josiah Jacob ${ }^{1}$, Shem yunusa bajama ${ }^{2}$, Yusha'u Ishaya ${ }^{3}$, Shunom Yem Gimson ${ }^{4}$ \\ ${ }^{1}$ Department of Banking and Finance Ahmadu Bello University, zaria \\ ${ }^{2}$ Department of Business administration, Federal university Gashua \\ ${ }^{3}$ Department of Business administration Federal university Gashua \\ ${ }^{4}$ Department of public Administration, Federal polytechnic kaura namoda, zamfara
}

\begin{abstract}
The study assessed the Effects of Discipline on Staff Performance in Local Government. The study was conducted in Giwa Local Government Area, Kaduna State. The study is a qualitative research method. Four research objectives were stated with four correspondent research questions and three assumptions. The instrument used for collecting data for the study was focus group discussion. Data were collected from respondents drawn from Giwa Local Government Area. Data collected were analyzed qualitatively. The study revealed that lack of discipline in the Local Government is sine qua non to the failures in the achievement of the desire, designed goals and objectives of Local Government and as such noted that Giwa Local Government should see discipline as an integral part of staff performance. The first finding showed that, Kaduna State Government through the adaptation of APER (Annual Performance and Evaluation Reports) has conditioned and discipline the staff as those discipline are partially promoted. The study also revealed that discipline has contributed to the development of Giwa Local Government as such recommends that certain incentives should be provided to energize the commitment of the disciplined staff so as to satisfactorily perform their assigned jobs in the Local Government Area.
\end{abstract}

\section{INTRODUCTION}

\subsection{Background to the Study}

There is no doubt that institutions and organizations worldwide either private or public are striving for success and competing those in the same business environment. In order to do so, organizations have to obtain, utilize, motivate and discipline her human resources effectively to achieve performance. Accordingly Asim (2013) noted that organizations and institutions need to be aware and pay special attention to all the core functions and duties of human resource management as this plays an important role in different social and economically related areas among others that are influential to the attainment of the organizational goals and thus her successful development in the long run. This implies that to understand the critical importance and behaviour of people in an organization is to recognize that the human element and the organization are synonymous.

In this regard, Usman (2018) opined that staffing is integral part of management and job satisfaction. Hence, to achieve a maximum output or productivity, employers in any organization should, as a matter of policy and necessity, discipline their staff to appraise their performance. This implies that the policies formulated in any organization cannot be enthusiastically and successfully implemented when the employees are not disciplined and are very apathetic with the conditions prevailing in their workplace. That is why Usman (2018) noted that lack of discipline of employees in any organization is sine qua non to the failures in the achievement of the desired and designed goals and objectives of the organizational system. Hence, discipline is inextricably tied with productivity and performance as such the employee's realization of this will make him to effectively and efficiently perform his task. These issues, therefore, constitute the primary assumptions in this study and hence become the preconditions in achieving the laid down objectives of Local Government.

Prior to the third republic in Nigeria, there has been a general resistance on some aspect of staffing in the public service because of the belief that all staff hired under a merit system must be presumed to be disciplined and enthusiastic about their jobs. This assumption was later jettisoned as the need for proper staffing became obvious in the public sector together with the expanding roles of the government. Training, promotion and discipline further became necessary in view of changing and growing complexity of employees' behaviour toward jobs assigned to them (Okwudili et al., 2010). 


\section{The Contribution of Staff Discipline and Promotion on the Development of Giwa Local Government Area}

Bearing in mind that discipline is integral and core to staff performance, Kaduna State Government has made effort through the Ministry for Local Government have adopted Annual Performance Evaluation Report (APER) to develop a condition and scheme to control and direct the behaviour of staff in the Local Government. This is with a view of making the employees of the Local Governments not only discipline but to be motivated and satisfied with the work they perform. Owing to this, Isha (2009) noted that these comprehensive, attractive and tempting conditions of service, staff regulations and scheme of service in the Local Government system must be adequately comparable with relevant private organizational structure. This organizational structure must condition the behavior of staff towards work so as to ensure performance, productivity and development. This implies that Kaduna State Government must make sure that discipline is attached with promotion so as to produce performance and develop a spirit of cooperation and sense of commitment and satisfaction within the Local Government.

Thus, the importance of discipline towards staff performance and Local Governments development cannot be underestimated. As a result, assessing the effects of discipline on staff performance in Giwa Local Government is at this time opted.

\subsection{Statement of the Problem}

The study set to assess the effects discipline on staff performance with particular reference to Giwa Local Government. Despite the adaptation of APER and the effort made by Kaduna state Government to develop a condition and scheme of service to control and direct the behaviour of staff in the Local Government, much result has not been recorded as most staff are not disciplined which has affected their performance and the development of the study area. The consequence is exemplified in the increase undisciplined attitude portrayed by most senior and junior staff in Giwa Local Government. This however, is associated with various factors which include lack of supervision, lack of evaluation of performance, poor criteria to motivate staff, irregular promotion and placement exercise, godfatherism and corruption.

Problems however, arise when Local Government staffs as important actors and stakeholders in Local Government development are not disciplined. This leaves the Government at risk of losing a huge sum of money as staffs who misbehave cannot be directed or controlled. In view of the foregoing therefore, the study raised the following research question.

i. $\quad$ To what extent can discipline improve staff performance in Giwa Local Government Area?

ii. What are the factors that cause staff indiscipline in Giwa Local Government Area?

iii. What are the criteria put in place to encourage disciplined staff in Giwa Local Government Area?

iv. What are the measures put in place by the State Government to ensure that staff are disciplined in Giwa Local Government Area?

\subsection{Objectives of the Study}

The main aim of the study is to assess the effects discipline on staff performance with particular reference to Giwa Local Government Area, while the specific objectives are:

i. To examine the extent discipline can improve staff performance in Giwa Local Government Area.

ii. To identify the factors that causes staff indiscipline in Giwa Local Government Area.

iii. To examine the criteria put in place to encourage disciplined staff in Giwa Local Government Area.

iv. To ascertain the measures put in place by the State Government to ensure that staff are disciplined in Giwa Local Government Area.

\section{$1.4 \quad$ Research Assumption}

This research is guided by the following assumptions:

i. Discipline cannot improve the performance of staff in in Giwa Local Government Area.

ii. The measures put in place by State Government cannot discipline staff in Giwa Local Government Area.

\subsection{Significance of the Study}

There have been several studies on the impact of staffing on employees' performance by different writers, but this study, as a point of departure looked at the effects of discipline on staff performance with particular reference to Giwa Local Government Area. This study is therefore justified because it has both practical and theoretical significance.

Practically, by establishing the fact that any Local Government Area that ensure discipline will achieve certain level of productivity and development. Theoretically, by establishing that an organization is effective to the degree to which it achieves its goals when it makes sure that there is proper staffing. Understanding the importance of discipline on staff performance and Local Government development, the findings would be significant to government in that it will serve as a guide when making policies on staffing in the Local Government Area. 


\section{The Contribution of Staff Discipline and Promotion on the Development of Giwa Local Government Area}

Also, the uniqueness of this research work would proffer solutions to the problems of inactivity and lack of discipline in Giwa Local Government Area and Nigeria in general. Furthermore, this research would help Governments, private organization, NGOs and donor agencies on how to effectively discipline staff in an organization. Finally, the method used by the study would also help further researcher and contribute to the existing literature in the field of staff discipline. It would also act as a stimulus for further research to refine and extend the present study especially in Nigeria.

\subsection{Scope and Limitation of the Study}

This research study is limited to Giwa Local Government Area alone where the researcher appraised out the effects of discipline on staff performance in Giwa Local Government between 2012 and 2017. In doing so the study collected data from secondary and primary source and use mixed method in analysing the data so as to test the validity of the findings.

\subsection{Research Methodology}

This research study is influenced by the muse to assess the effect of discipline on staff performance in Giwa Local Government Area. In doing so the study collected data from primary and secondary source. While the secondary data were sourced from journals, seminar papers and textbooks in the department library, the primary data was sourced from respondents drawn from Giwa Local Government Area in a Focus Group Discussion. Hence, since the researcher used focus group discussions (FGD) the sample size was limited to 9 persons from the targeted group interviewed in the focus group discussion. This was done to triangulate views because a large percentage of these groups are directly or indirectly affected by the issue discussed. Also, the study employed the use of stratified random sampling technique. In using this technique, the study divided the respondents' base on their characteristic in groups and discuss with them. This was to enable the researcher get first-hand information that would help enrich the substance of the data collected. Subject to the above issue, the study analysed data generated from the field qualitatively.

\subsection{Operational Definition of Terms}

Staff: All the people or group of individual employed by organizations who work part-time or full-time under a contract of employment, whether oral or written, express or implied, and have recognized rights and duties (Wikipedia, 2018). They can also be seen as people who work for an organization or a business firm either for pay or free.

Discipline: The practice of training people to obey rules or a code of behaviour, using punishment to correct disobedience. Staff discipline is a management function in organizations. Discipline, according to McFarland (1979), refers to conditions of orderliness set to control and direct human behaviour.

Staff Discipline: This is the corrective action or measure taken by an organization to ensure that staff adheres to rules and regulations guiding the operation of activities in the organization. It is an indispensable tool of control applied in organizations in order to achieve organizational objectives (Ona, 2003).

Performance: This is completion of a task with application of knowledge, skills and abilities. In work place, performance or job performance means good ranking with the hypothesized conception of requirements of a task role.

Staff Performance: Performance is an outcome that you want to accomplish by every organization, both public and private organizations. Good organization is the organization that has been able to create a good performance.

\section{LITERATURE REVIEW AND THEORETICAL FRAMEWORK}

\subsection{Introduction}

The main focus of this chapter is to identify and critically review some noticeable literatures that are related to the subject matter under study that addresses the research questions. This was done under the following sub themes: The Concept of Discipline; The Concept of Performance; The impact of staff discipline and performance.

\subsection{The Concept of Discipline}

Discipline, according to McFarland (1979), refers to conditions of orderliness in which members of an organization conduct themselves with respect of the needs and desires of the organization, subordinating to some extent their own needs and desires. We see discipline as concern with the imposition of certain restrictions on the behaviour of members (employees) of an organization. There are two basic forms of discipline, namely, positive or constructive discipline on the one hand and negative discipline on the other. Positive discipline means the fostering of co-operation and a high level of morale so that the written and unwritten rules and conditions are obeyed willingly by employees. These rules may cover general terms of employment, hour of work, communication channels, performance standards, organizational expectations and general employees conduct (Onah, 2003). It also embraces good behaviour by managers or supervisors, such as good supervision, treating all employees fairly, 


\section{The Contribution of Staff Discipline and Promotion on the Development of Giwa Local Government Area}

eschewing bad manners, being helpful and considerate to staff and setting of good examples by not breaking any rules (Achebe, 1986; in Osezua et al., (2009)

Staff discipline is a management function in organizations. It is an indispensable tool of control applied in organizations in order to achieve organizational objectives. The importance of this fact lies in the fact that wherever people are working there must be problems of adjustment which demands that discipline is necessary in order to be able to correct deviations from laid down rules and procedures in organizations. For organizations to move forward there must be total elimination of insubordination to leaders, drunkenness and gross immorality among employees while in office premises, there must also be reasonable level of adherence to rules and regulations which are necessary towards maintaining punctuality and regularity to work,

In developing disciplinary policy in organizations in any disciplinary process, disciplinary policy and action must be shaped with labour and management in agreement. The reason for this is that, the worker of today is better than the worker of yesterday. The existence, of trade unionism gives today's worker more or better privileges and opportunities than the worker of yesterday. Discipline may make and individual do jus the basic (minimum best). He will just do his work to avoid being punished. Threats and punishment can only be effective where the worker under such condition is fairly a self-confident individual who remains effective under threat. He must feel that no other better alternatives to working for his organization are available at that time. His motivational pattern is like that of a psychologically primitive individual who requires no external force to push him to consider higher level accomplishments. Furthermore they may precipitate to a retaliatory or defensive behavior, thus, threats and punishments are poor motivators (Osezua et al., (2009).

For the public service which includes the Local Government system to perform effectively, there is need not only to motivate workers but also to in-still a very high degree of discipline, thus, reward and punishment go hand in hand. Discipline and some of its procedures had been criticized in the past. The massive purge in the public service which affected all categories of Civil Servants in 1975 had a devastating effect on the efficiency of the public service. It led to a feeling of insecurity and selfconfidence which led to over caution and cynicism on the part of the workers. Fear of a purge is de-motivating even if the thing feared does not materialize. Purge is not the best way of purifying the public service or ensuring discipline and productivity. Large scale purge of the civil servants should as far as possible be avoided because whatever the original intention, they tend to degenerate into witch-hunting and destabilizes the government itself and society at large. However, it will be better to incorporate in the civil service rules, whatever conditions of service or rules of behaviour that are considered desirable and try to enforce them like other rules and conditions Osezua et al., (2009).

\subsubsection{Types of Discipline}

Discipline can either be self-imposed or imposed by others. Self-imposed discipline is spontaneous, self-generated or internally generated. It manifests in systematic mode of behaviour, obedience to rules as a result of inner conviction of their advantages, conformity to norms, rules, regulations and orderliness without external imposition. Discipline is self-imposed if conforming to rules and standards is accepted by the individual as either constitutive of what is to be achieved or a means of doing something that he wants to do or thinks desirable, for example, when a child loves music and sets about learning to play or sing, subjecting himself to the discipline of music or when he becomes fascinated by the habits of animals and sets to work to understand how and why animals behave the way they do; or when a person submits to regular exercise in order to keep healthy or when a person diets in order to reduce weight (Garima, 2013).

These cases of self-discipline are considered to be desirable in organizations because the submission to rules springs from the individual's own decisions in which some kind of autonomy or freedom is displayed. Some people believe that freedom is the ability to control one's passions, impulses, drives and desires. In other words, freedom is self-control. It is obvious that somebody who cannot stop himself from taking alcohol or smoking or taking hard drugs such as cocaine or marijuana or having sex is not free and cannot be autonomous or reliable Self-discipline contrasts with discipline imposed by others through sanctions, punishment or threats of punishment (Garima, 2013). Externally imposed discipline springs from other people's desires such as parents, organizations, peer groups and the church. It should be noted that the person's desires and decisions are involved in these too. An employee may want to avoid the disapproval of management in certain things in the organization or punishment and so obeys rules. Offering staff's prizes at the end of every year based on their performances during the year is also an externally imposed form of discipline just as much as coercing them by threats of punishment. In externally imposed discipline, the person is made to do what others want by manipulating him and playing on his desires and fears. Self-discipline is a preferred form of discipline. It is closely connected with autonomy (self-direction). Integrity and courage are involved in selfdiscipline and they are virtues which have to be exercised in the face of counter inclinations (Osezua et al., 2009) 


\section{The Contribution of Staff Discipline and Promotion on the Development of Giwa Local Government Area}

\subsection{Theoretical framework}

The research work is anchored on systems theory proposed in the 1940's by the biologist Ludwig von Bertalanffy (General Systems Theory, 1968), and furthered by Ross Ashby in 2009 and Emeh and Ikechukwu in 2012. Von Bertalanffy was both reacting against reductionism and attempting to revive the unity of science. He emphasised that real systems are open to, and interact with, their environments, and that they can acquire qualitatively new properties through emergence, resulting in continual evolution. Rather than reducing an entity (e.g. the human body) to the properties of its parts or elements (e.g. organs or cells). Systems theory focuses on the arrangement of and relations between the parts which connect work and activities into a whole. Von Bertalanffy (1956) opined that systems concepts include: system-environment boundary, input, output, process. According to Emeh and Ikechukwu (2012) INPUT, PROCESS and OUTPUT; can be applicable to Local Government system.

2.4.1 Inputs: These are human and material factors supplied to the system which are transformed into productive services. As an open system, the Local Government will appraise and assess the performance of staff as input or demands in the form of promotion to satisfy employee's interest while support is rendered when the staff supports and perform better his job, by obeying bye-law (discipline). That is, while the Local Government system contributes their best in promoting dedicated, loyal and serious staff, punishment will be arranged for undisciplined staff. Such demands in this research are ensuring that Local Government staff are well disciplined and dully promoted. However, these are just demands made by the Local Government on the staff (Emeh and Ikechukwu, 2012).

2.4.2 Conversion Processes: The inputs have to be converted, that is demand for promotion and discipline should improve the productiveness of employees and also help the economic development of the Local Government. This is why this process is called conversion process. This is the process by which inputs (demand for promotion and discipline) are changed into output (performance and productivity) which is referred to as transformation. Since the Kaduna State Governments have inputs like promotion, public funds, various categories of staff and delivery of services decisions must be reach to enhance performance. This is why it is a system, as such staffing as a decisions, actions and inactions must be converted into inputs and subsequently outputs (Emeh and Ikechukwu, 2012).

2.4.3 Output: The performance that is produced by the staff of Giwa Local Government must be sent out to the authority of the State Government as end product or output. In the case the promotion of the employees depends of the level of his productivity (Emeh and Ikechukwu, 2012).

2.4.4 Feedback: The various cycled nature of the system is accounted for by feedback. In other words, some of the systems outputs are sent back into the system as new inputs or demands which lead to future output and so on in a continuing-neverending flow of the system. Giwa Local Government as an open system receives input in the form of salaries, promotion and the provision of services and amenities based on their erstwhile demands. In our context, since the Government have provided these the staff are expected to obey laws, be discipline and productive. Also, the Government having provided an annual performance and evaluation report files for the staff, it is expected that the staff will be well disciplined and promoted as the case may be. Our emphasis here is that it is this feedback mechanism that makes systems theory/approach complete (Emeh and Ikechukwu, 2012).

2.4.5 Interdependence: This is the inter-working relationship between the parts of the system and the whole system. This shows that when a part of the system is affected in the course of any action, the various departments in Giwa Local Government is also affected. The State Government, Giwa Local Government and her staff are all interrelated to each other because they are all working towards the same goal "the achievement of socio-economic and political development of the Local Government system (Emeh and Ikechukwu, 2012).

\subsection{The Relevance of System Theory to this Study}

It is revealed that Local Government also target productivity and development which is also under the study of public administration. This means that the solution embedded in productivity and development is also of Giwa Local Government concern. Therefore a study of the contribution of staff promotion and discipline in development of Local Government should be studied with systems approach and to ensure that, the systems theory becomes eminent as cited by Emeh, and Ikechukwu (2012). According to the systems theorists, "a system is essentially an assemblage of things interconnected or independent, so as to form a complex unity". Giwa Local Government Area interacts and functioned with employees who are also influenced by their environment (political, social, economic, ethical, technological etc) and in turn, influence its environment. Worthy of note is that a system needs support from environment in order to survive. Thus, when the State Government receives inputs of support from her employees such as discipline, obedience to rules and regulations etc, they will equally motivate the employees by promoting them. Equally important to Giwa Local Government is to note that consequent upon staff outputs, some new 


\section{The Contribution of Staff Discipline and Promotion on the Development of Giwa Local Government Area}

inputs are generated and fed back into the system through the feedback mechanism. These are, again, processed and converted to output.

Giwa Local Government Area is represented as receiving inputs from the environment in the form of the demands from citizens for the provision of welfare package, as such her employees must work very hard to produce a desire result and by extension the Local Government will motivate the employees by promoting them accordingly and periodically. Giwa Local Government processes these demands within their administration; the results at the end of the processing stage are collectively regarded as the outputs. They consist of the relative orderliness of the community, the level of staff performance and seriousness, and the timeliness of their delivery. In other words, Giwa Local Government requires interrelated elements with daily interaction between external and internal (staff) environments. This means that to solve the problem of unproductivity in Giwa Local Government, there must be a consideration of the important of staffing or human resource management as a tool for improving staff performance. This is because, for problems like indiscipline, unproductiveness and non-promotion to be solve its solutions are not sacrosanct with Giwa Local Government provision motivating her staff but others sources which can emanate from the environment. For instance, staff who are well disciplined and promoted they will be motivated to acquire more skills and knowledge. Thus, for the purpose of productivity and development in Giwa Local Government the decisions to develop appraise the performance of staff is very essential.

It is revealed that Local Government also target productivity and development which is also under the study of public administration. This means that the solution embedded in productivity and development is also of Giwa Local Government concern. Therefore a study of the effects of discipline on staff performance in development of Local Government should be studied with progressive and punitive theory of discipline to ensure that staff in the local government will perform better. According to this theory staff in Giwa Local Government Area must be appraised for effective performance. The theory emphasized on getting the employee to learn from past mistakes and initiate a plan to make a positive change in behavior. This implies that rather than depending on threats and punishment, staff should be supervised and counseling skills should be initiated to motivate the staff in the Local Government. It also state that rather than placing blame on the staff, the authority of the Local Government should appoint supervisors to emphasize on collaborative problem solving. The theory alters the supervisor's role from adversary to counselor (Baron, 2009). To ensure that supervisors are adequately prepared to counsel staff, Giwa Local Government should apply positive and punitive discipline to see that they receive appropriate training either from the Local Government own human resource department or from outside professionals.

The theory noted that disciplinary procedure starts with counseling session between staff and Giwa Local Government authorities which ends with a verbal solution that is acceptable to both parties. If this solution does not work, the staff and Giwa Local Government authorities meet again to discuss why it failed and to develop a new plan and timetable to solve the problem. At this stage, the newly agreed upon- solution to the problem is written down. If there is still no improvement in performance, the third step is a final warning that the staff is at risk of being discharged from work. This third step gives the staff some time to evaluate his or her situation and come up with a new solution. In doing so the staff is encouraged to examine why earlier attempts to improve performance did not work. Some organization even give their employee a decision-making day off' with pay to develop a plan for improved performance. This theory is important because it will help Giwa Local Government. Also staff in Giwa Local Government will prefer it because they like being treated with respect by their authorities, while Giwa Local Government authorities will prefer it because it does not demand that they assume the role of disciplinarian thereby improving working relationship at the Local Government.

\section{DATA ANALYSIS AND PRESENTATION}

\subsection{Data Presentation and Analysis}

In order to enrich the validity of the study conclusion, purposive sampling as a methodology of data collection was employed which allowed the study to collect data through interview in a focus group discussion. Hence, nine (9) respondents are interviewed based on the subject matter. The responses were critically analysed such that the conclusion of the findings can be tested scientifically. The analysis was done based on each research questions and the raw data was analysed in tandem with the respondent's responses as coded and categorized.

\subsection{Relating Research Assumptions with Data}

Relating the first research assumptions with data, it shows that discipline can improve performance in the Local Government Area. This has significantly affirmed to the research assumption which states can improve staff performance and also ensure development in Giwa Local Government Area. With this, the data has answered the first research question. Though the data 


\section{The Contribution of Staff Discipline and Promotion on the Development of Giwa Local Government Area}

revealed that some staff in Giwa Local Government were not dully promoted as such it affect their performance, hence, the Government must address this issues in order to motivate the troubled staff.

Relating the second research assumptions with data, it shows that there lack of supervision, lack of evaluation of performance, poor criteria to motivate staff, irregular promotion and placement exercise, godfatherism and corruption are some of the factors that encourage indiscipline in Giwa Local Government Area. This has significantly affirmed to the research assumption which states that there are factors that encourage indiscipline in Giwa Local Government Area. With this, the data has answered the second research question. Though the data identified some of these factors, hence, the Government must of necessity address these issues to achieve a desire result. Even though literature reviewed shows that staff discipline can ensure development in Giwa Local Government Area, some many senior staff are not discipline but are productive even though they don't respect law and order. The data also revealed that the measures put in place by State Government have ensured discipline because many staff have been promoted using the annual performance and evaluation report (APER).

\subsection{Major/Key Findings}

The main objective of the study is to examine the effects discipline on staff performance in Giwa Local Government Area. In doing this the study discovered that:

i. Even though some staff feels they are above the law, those that are undisciplined are dully penalized and punished as the case may be in Giwa Local Government Area.

ii. All the staffs (junior and senior as well as political and administrative) are to some extent disciplined except in some case. It also revealed that some individuals in Giwa Local Government feel they can't be controlled or disciplined.

iii. Staffs are periodically promoted in accordance with the provisions in the scheme. This however encourage staffs be to proactive, committed and serious about their jobs.

iv. Kaduna State Government has made efforts to ensure that staffs are dully promoted and disciplined in Giwa Local Government.

v. Discipline has to a greater extent inprove the performance of staff in Giwa Local Government Area.

vi. The criteria put in place for the promotion and discipline of staff in Giwa Local Government Area is effective as staff are occasionally supervise.

\subsection{Discussion of Results}

This work interviewed respondents in a focus group discussion to examine the effects of discipline on staff performance in Giwa Local Government Area. This discussion was conducted with 9 respondents to collect first-hand information on the subject matter. However, their responses indicated that discipline has helped to a greater extent improve the performance of staff and the development of Giwa Local Government Area. Their responses also indicated that the measures put in place by State Government have conditioned the attitudes of staff. This is to say that, staff that are discipline are promoted to enhanced and improve their level of productivity and performance so as to develop Giwa Local Government Area. Hence, the measures put in place to direct and control the attitude of staff in Giwa Local Government has made a significant impact.

\section{CONCLUSION AND RECOMMENDATION}

In this chapter the researcher would summarize, conclude and draw relevant recommendation based on the subject matter.

\subsection{Conclusion}

In conclusion, the study established that staffing is core and central to employee's performance and the achievement of predetermined goals. As such organizations and institutions need to be aware and pay special attention to all the core functions and duties of human resource management as this plays an important role in different social and economically related areas among others that are influential to the attainment of the organizational goals and thus her successful development in the long run. This implies that staffing has a significant relationship with how best an employee performs their expected role.

Also, discipline can improve staff performance and level of productivity. This implies that productivity can be increased in the public sector if deliberate attempts are made to discipline staff and to address other issues bothering on staffing in the workforce. This is because acts of discipline are unsatisfactorily measures that help unstrengthen the overall system of an organization for higher productivity. In the foregoing therefore, ensuring discipline of employees is both a prerequisite condition for any organization to achieve its objectives and greatness. In Giwa Local Government Area, however, due to the dearth of the required number of incompetent personnel, appropriate policy guidelines and infrastructural facilities, it is difficult, if not impossible, to motivate employees in this Local Government. It is, therefore, imperative to discipline and motivate the existing staff through promotion with a view to achieving the primary aim and objectives of the Local Government system. 


\section{The Contribution of Staff Discipline and Promotion on the Development of Giwa Local Government Area}

\subsection{Recommendations}

This work recommends as follows:

i. Staffs that are undisciplined should be dully penalized and punished as the case may be. This will serve as a control measures for checking and guiding other staffs that want to be undisciplined.

ii. The Government should ensure that punishment and penalties are set for undisciplined staffs according to grade level. Also they should ensure that the Annual performance appraisal report (APER) file is strictly supervised.

iii. The Government should ensure that those individuals who feel they can't be controlled or disciplined are controlled and punishment as their attitude may result to general indiscipline. The Local Government as a point of duty should aim at very regular supervision of members of their staff, especially those who feel they are above the law. This should be made a culture in Giwa Local government.

iv. Government as a matter of policy should apply some very dynamic approaches that can lead to more effective disciplinary control in Giwa Local Government system, for instance Staffs who are found guilty of embezzling government funds should be made to pay back immediately. In case of refusal to pay their properly should be impounded and out rightly sold to the public.

\section{REFERENCE}

1) Amir Elnaga1 Amen Imran and Amen Imran (2013) The Effect of Training on Employee Performance: .European Journal of Business and Management ISSN 2222-1905 (Paper) ISSN 2222-2839 (Online) Vol.5, No.4, 2013

2) Aarti, C., Seema, C., Bhawna,C. \& Jyoti, C. (2013). Job Satisfaction Among Bank Employees: An Analysis Of The Contributing Variables Towards Job Satisfaction. International Journal of Scientific \&Technology Research, 2(8), 11-20.

3) Amin, A. et al. (2013). The Impact of Employees Training On the Job Performance in Education Sector of Pakistan. Middle-East Journal of Scientific Research 17 (9), 1273-1278.

4) Asim, M. (2013). Impact of Motivation on Employee Performance with Effect of Training: Specific to Education Sector in Pakistan. International Journal of Scientific and Research Publications, 3(9), 1-9

5) Baruch, Y. (2006), "Career development in organizations and beyond: balancing traditional and contemporary viewpoints", Human Resource Management Review, Vol. 16, pp. 125-38.

6) Cheramie, R.A., Sturman, M.C. and Walsh, K. (2007), "Executive career management: switching organizations and the boundary less career", Journal of Vocational Behavior.

7) Isah Mohammed Abbass (2009) Motivation and Local Government Employees in Nigeria: European Scientific Journal edition vol. 8, no.18 issn: 1857 - 7881 (print) e - issn 1857- 7431

8) Kim, S. (2006), "Public service motivation and organizational citizenship behavior in Korea", International Journal of Manpower, Vol. 26 No. 8, pp. 722-40

9) Okwudili Chukwuma Nwosu And, Emmanuel Ugwuerua (2015) Staff Discipline in the Nigerian Local Government System: IOSR Journal Of Humanities And Social Science (IOSR-JHSS) Volume 20, Issue 7, Ver. I (July 2015), PP 38-45 eISSN: 2279-0837, p-ISSN: 2279-0845.

10) Osezua M. Ehiyamen, Abah Emmmanuel O. And Daniel E. Gberevbie (2009) Staff Indiscipline and Productivity in the Public Sector in Nigeria (Pp. 461-471): An International Multi-Disciplinary Journal, Ethiopia Vol. 3 (4), July, 2009 ISSN 1994-9057 (Print)

11) Pfeifer, C., Janssen, S., Yang, P. \& Backes-Gellner, U. (2011). Effects of Training on Employee Suggestions and Promotions in an Internal Labour Market. Working Paper Series in Economics No. 202, University of Lüneburg

12) Usman Abubakar (2018). Lecture note on Theories and Practice of Management

13) Saeed, M. M. \& Asghar, M. A (2012). Examining the Relationship between Training, Motivation and Employees Job Performance - The Moderating Role of Person Job Fit. Journal of Basic and Applied Scientific Research, 2(12)1217712183

14) Saleem, Q., Shahid, M. \&Naseem, A. (2011). Degree of influence of training and development on employee's behavior. International Journal of Computing and Business Research, 2(3): 2229-6166

15) Seijts, G., \& Crim, D. (2009). The combined effects of goal type and cognitive ability on performance. Motivation and Emotion.

16) Stephen Ocheni, Moses Atakpa and Basil C. Nwankwo (2013) The Nigerian Union of Local Government Employees (NULGE) and Promotion of Good Employer-Employee Relations in Nigeria Local Government Service in the 21st Century: Mediterranean Journal of Social Sciences Published by MCSER-CEMAS-Sapienza University of Rome Vol 4 No 2 
The Contribution of Staff Discipline and Promotion on the Development of Giwa Local Government Area

APPENDIX

CHECK LIST OF INTERVIEW SCHEDULE FOR RESPONDENT IN FOCUS GROUP DISCUSSION

i. To what extent can you say that staff are disciplined in Giwa Local Government

ii. Which categories of staff are the most disciplined in Giwa Local Government Area?

iii. Do some individuals in Giwa Local Government feel they can't be controlled or disciplined?

iv. What is the reward for discipline in Giwa Local Government?

v. What are the criteria put in place to encourage disciplined staff in Giwa Local Government Area

vi. To what extend are disciplined staff in Giwa Local Government regularly and periodically promoted in accordance with the provisions in the scheme of service?

vii. To what extend has discipline improve staffs performance and enhanced their level of commitment and productivity in Giwa Local Government

viii. What are the efforts made by Kaduna State Government to ensure that staffs are dully promoted and disciplined in Giwa Local Government? 